\title{
Nano fragility
}

\section{Michal Gavish}

Washington, DC, USA

Correspondence to: Michal Gavish. Washington, DC, USA. Email: 4michalgavish@gmail.com.

Submitted Oct 21, 2019. Accepted for publication Oct 28, 2019.

doi: $10.21037 /$ cdt.2019.10.08

View this article at: http://dx.doi.org/10.21037/cdt.2019.10.08

As a chemist and artist, I experiment with expressing environmental concerns on the most basic molecular levels. Using microscopes and collaborative laboratory data, I focus on the stress on DNA and proteins in the changing environment (Figure 1,2). Collaborating with scientists, I create art based on specific scientific models. My process begins by adopting the old tradition of nature drawings that I modify by constantly searching for new materials. I take the small structures that we cannot see and gives them color and volume. I layer and magnify (Figures 1-3) the scientific imagery to human scale, preserving its biological integrity. Considering their frailty, I give a new presence to these previously invisible, living formations. The soft installations and fragile materials examine the delicate balance that is essential for bio-structures and their vitality (Figures 3-5).

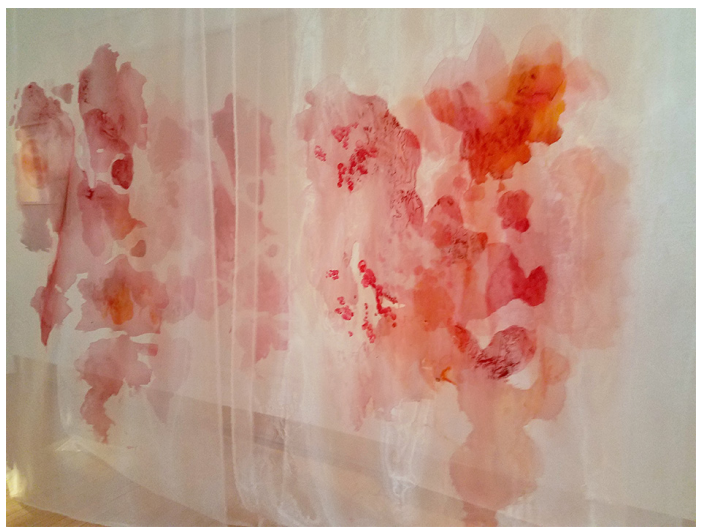

Figure 1 Hidden Features (Protein Microscopy), 2019. Mixed media on paper and fabric, based on microscopy images by Prof. Onn Brandmann, Biology Dept, Stanford University, CA; $5 \times(92 " \times 60 " \times 30 ")$.

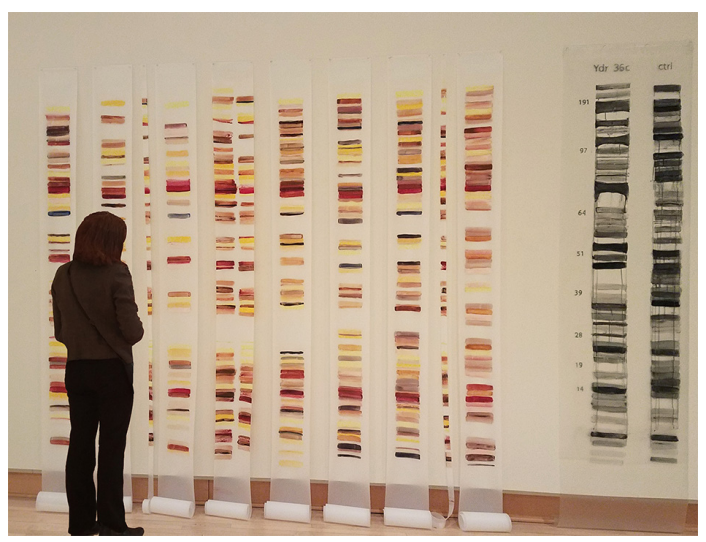

Figure 2 Fine Sorting, 2019. Mixed media plastic installation based on Electrophoresis images by Prof. Onn Brandmann, Biology Dept, Stanford University, CA; $8 \times(92 " \times 10 ")+90 \times 25 "$.

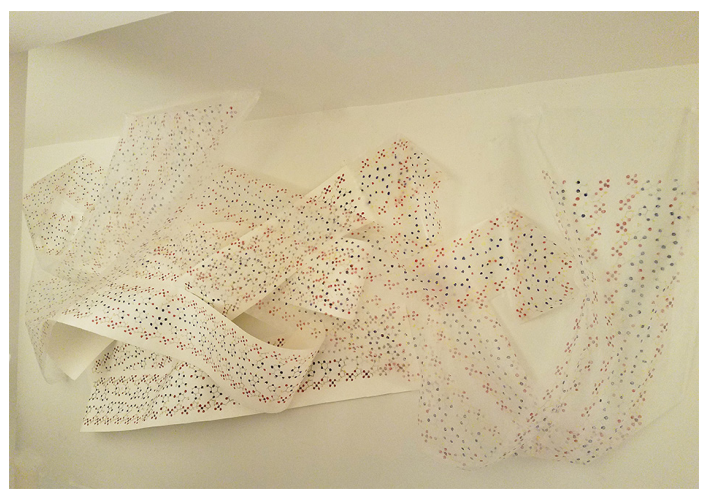

Figure 3 Dimensional Fragility, 2019. Mixed media on paper and fabric. Dimensions variable. 


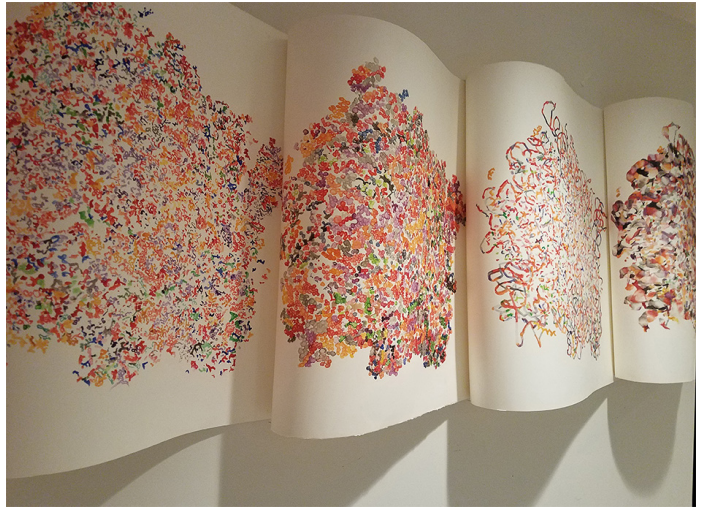

Figure 4 Protein scrolls 2017-19. Acrylic on paper and plastic based on X-ray models. Modular $5 \times(27 " \times 80 " \times 20 ")$.

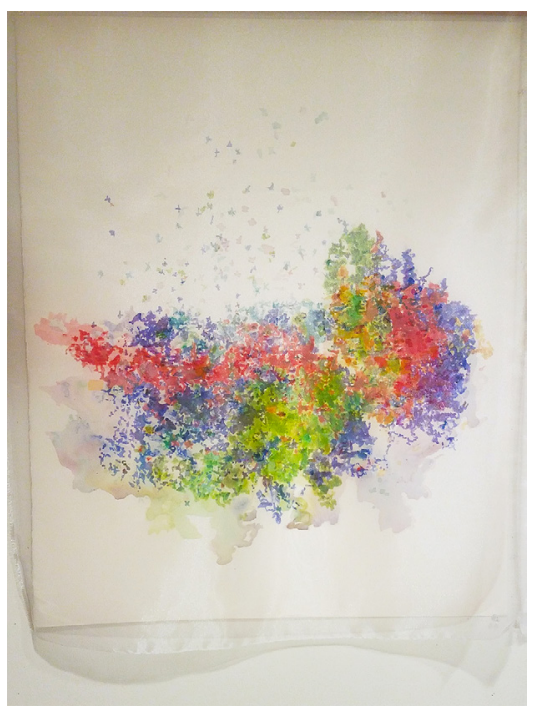

Figure 5 Protein model 2019. Mixed media on fabric based on X-ray models. Modular 28"×36".

\section{Artist biography}

Michal Gavish is a multi-media artist and a freelance art reviewer. Her work is exhibited in solo and group shows nationally and internationally. She received her MFA in painting from the San Francisco Art Institute. Previously, she had earned a $\mathrm{PhD}$ in Physical Chemistry, which continues to influence her art practice. She creates installations and videos inspired by her science background and her ongoing collaborations with scientists. Recently she was featured in a book about 18 contemporary women artists. Gavish has co-curated group shows in New York. She lectures and teaches college art and science.

\section{Acknowledgments}

Funding: None.

\section{Footnote}

Conflicts of Interest: The author has completed the ICMJE uniform disclosure form (available at http://dx.doi. org/10.21037/cdt.2019.10.08). The author has no conflicts of interest to declare.

Ethical Statement: The authors are accountable for all aspects of the work in ensuring that questions related to the accuracy or integrity of any part of the work are appropriately investigated and resolved.

Open Access Statement: This is an Open Access article distributed in accordance with the Creative Commons Attribution-NonCommercial-NoDerivs 4.0 International License (CC BY-NC-ND 4.0), which permits the noncommercial replication and distribution of the article with the strict proviso that no changes or edits are made and the original work is properly cited (including links to both the formal publication through the relevant DOI and the license). See: https://creativecommons.org/licenses/by-nc-nd/4.0/.

Cite this article as: Gavish M. Nano fragility. Cardiovasc Diagn Ther 2020;10(2):386-387. doi: 10.21037/cdt.2019.10.08 